\title{
Livelihood Diversification: A Streatagy for Rural Income Enhancement
}

\author{
Muhammad Israr ${ }^{1, *}$, Humayun Khan ${ }^{2}$, Dawood Jan ${ }^{3}$, Nafees Ahmad ${ }^{4}$ \\ ${ }^{1}$ Assistant Professor and Head of Department, Department of Rural Development, Amir Muhammad Khan Campus, Mardan, The \\ University of Agriculture-Peshawar, Khyber Pakhtunkhwa-Pakistan \\ ${ }^{2}$ Professor, Institute of Development Studies, The University of Agriculture-Peshawar, Khyber Pakhtunkhwa-Pakistan \\ ${ }^{3}$ Associate Professor, Department of Agriculture and Applied Economics, The University of Agriculture-Peshawar, Khyber \\ Pakhtunkhwa-Pakistan \\ ${ }^{4}$ Lecturer Department of Economics, University of Malakand, Chakdara (Dir Lower), KP-Pakistan \\ *Corresponding author: israrids@yahoo.com
}

Received September 05, 2014; Revised September 11, 2014; Accepted September 29, 2014

\begin{abstract}
The aim of this study was to study the diversified income, its contribution and the effect of income of the households in Shangla district of Khyber Pakhtunkhwa, Pakistan. Data were collected from 323 households through face to face interviews with the help of a structured questionnaire. The empirical evidence shows that among the farm sources of livelihood the crop and livestock activities of the household were diversified and have been increased. The adoption of latest seed technologies of maize and wheat had increased the productivity and hence income of the farm households. The sample respondents had also diversified livestock activities. Average income from crop was Rs. 65,350 per annum per household based on total household. While its contribution to total income was $15.08 \%$. Diversification was observed mainly in non-farm income sources. The overall non-farm income contribution to the total income after diversification was $69.40 \%$ and the average income was Rs. 300,811 per household per annum income. The contribution of total income from farm sources was decreased by $10.03 \%$ after the diversification of income. Agriculture to non- agriculture ratio decrease to 0.4408 after the diversification of income. Average income from the farm sources decreased while from non-farm sources increased. From all sources of income the change was Rs. 1,80,812 per annum per household. But the contribution of non-farm sources was more than the farm sources of income to the total household income. It was concluded from the findings that diversification had increased the household income. The area lack in development compared with other areas of the province. The study recommends further improvements in both the farm and non-farm sources of income for sustainable livelihood and this can be done by investing more in the productive capitals of the rural households.
\end{abstract}

Keywords: diversification, livelihood, farm to nonfarm diversification and ratio

Cite This Article: Muhammad Israr, Humayun Khan, Dawood Jan, and Nafees Ahmad, "Livelihood Diversification: A Streatagy for Rural Income Enhancement.” Journal of Finance and Economics vol. 2, no. 5 (2014): 194-198. doi: 10.12691/jfe-2-5-10.

\section{Introduction}

Livelihood diversification in the rural areas of the developing world got importance in the literature and research since the 1990s with the introduction of the livelihood frameworks. Several issues have received attention during the late nineties, when various studies verifying the diversity of rural livelihood strategy (Reardon, 1997) the determinants of diversification (Smith et al., 2001), favorable and unfavorable factors for diversification (Hussein and Nelson, 1998) its distributional effects and its relationship with agricultural productivity (Ellis, 2000).

Rural development has been an important policy goal for many developing countries, and large-scale, structural reform measures and poverty reduction have been taken to this end. The focus on livelihood is relevant, in particular, with the discussion on rural poverty reduction (Kim, 2011). Millions of rural people were able to escape poverty through better farm incomes, employment in agriculture, and rural nonfarm enterprises and through migration and hence contributed to better livelihood (World Bank, 2008).

Livelihood has become a popular concept in a development discourse. According to Chambers and Conway (1992) a widespread definition on the livelihood is "the capabilities, assets i.e. stores, resources, claims and access and activities required for a means of living”. Livelihood diversification has been always around in rural areas, its increasing significance in a rural life calls a renewed attention. With respect to on-farm diversification, farmers have increasingly established alternative or nonconventional farm enterprises beyond the traditional way of mixed cropping. (Diez et al., 2000).

Livelihood diversification implies a process of dynamic change and constant adaptation(Ellis, 2000). Attempts 
have been made by individuals and households to find new ways to raise incomes and reduce risk, which differ sharply by the degree of freedom of choice and the reversibility of the outcome. Livelihood diversification includes both on and off-farm activities which are undertaken to generate additional income from the major agricultural activities, via the production of subsidiary agricultural and non-agricultural goods and services, the sale of wage labor, or self-employment in small firms, and other strategies undertaken to minimize risk. These include activity or environment diversification in agriculture (Losch et al., 2010).

Risk and seasonality comprise two classic reasons for livelihood diversification. In order to minimize risks and secure a constant inflow of income despite different harvesting seasons, rural populations has pursued various income activities with different risk profiles. Securing a variety of income sources in preparation for a failure in a certain activity is a conventional wisdom reflected in the saying, "Do not put all your eggs in one basket". It is especially relevant in a rural context where unpredictable weather patterns and harvest performance make it difficult to secure a fixed amount of regular income (Ellis, 2005). Livelihood analysis is based on the assumption that the current livelihoods reflect people's rational choices. It focuses on the resilience of the poor and builds on their initiatives. Thus, it attempts to identify asset bases, livelihood strategy and desired goals of the poor in order to create an enabling environment to support them (Kim, 2011).

Diversification can be divided into two categories, onfarm and non-farm diversification. On-farm diversification means "maintenance of a diverse spread of crop and livestock production activities that interlock with each other in various ways”. A conventional example is a mixed cropping or intercropping, which refers to growing two or more crops on the same piece of land to "take advantage of complementarities between crops in their use of soil nutrients, sunlight and other resources" (Ellis, 2000). Non-farm diversification refers to seeking business or employment opportunities other than traditional crop production and livestock rearing. Even non-farm diversification is related to agriculture as it includes processing and trading of agricultural produce. Also, nonfarm activities include service provision, trade and business and manufacturing.

Resting on the importance of the diverse livelihood in the lives of the rural households the livelihood diversification is one of such dynamic phenomena now taking place in rural areas and thus needs more attention from policy makers. It is gaining renewed importance in rural population seeking sufficient livelihood under the limitations of traditional farming and increasing cash needs during this time of food insecurity and high population growth. In order to address these issues, present research is designed to this end with the following objectives.

1. To study the diversified income of the households in the study area

2. To identify the income contribution of the diversified income to the total household income

3. To study the change in the process of diversification in the area

\subsection{Hypothesis}

1. Diversification increases the household income.

2. The change in the farm source of income is more significant than the nonfarm source.

\section{Materials and Methods}

This research was confined to four union councils i.e. Shahpur, Lilownai, Kuzkana and Pirkhana of the Shangla district of Khyber Pakhtunkhwa, which was randomly selected. There are 111 villages in the sample union councils with 9,999 households. The household was taken as a unit of analysis and data were collected at the household level from the head of the household. It was not possible to collect information about a certain investigation of the total population due to financial and time constraints. Therefore, for this research the following formula of Cochran (1963) is used to determine the required sample size.

$$
n_{0}=\frac{Z p q^{2}}{e^{2}}
$$

where: $n_{0}=$ Sample size, $Z=$ Distance between the normal curves that cuts off an area at the tail. Its Value is constant and different for different percentages.

$\mathrm{p}=$ Variability, $\mathrm{q}=$ Precision, $\mathrm{e}=$ Error

Taking the constant value of $\mathrm{z}$ at $5 \%$ i.e. 1.96, variability $p(0.7)$, precision $q(0.3)$ and error e (0.05), the resulted sample size were 323 . Primary data on the household income strategy and diversification made in income in the last five years was collected from the sample respondents through a face to face interview with the help of a structured questionnaire. The collected primary data was analyzed by using descriptive statistics and different non-parametric tests.

\section{Results and Discussions}

\subsection{Household Income with Diversification}

Data in Table 1 show the household income from different sources after diversification. The results show that among the farm sources of livelihood the crop and livestock activities of the household were diversified and increased because of adopting the new varieties of maize and wheat crops which had increased the productivity and hence income of the household. The sample respondents had also diversified livestock activities. They were reared improved breeds of animals. The other sources of farm income i.e. fodder and vegetable cultivation, daily wages in agriculture and forest of the sample household remain unchanged. The findings show that the average income from crop was Rs. 65,350 per annum per household based on total household. While it contribution to total income was $15 \%$ while the average income based on the household reported income from the source was Rs. 80,552 per annum. Similarly the livestock income also increased and the average household based on total household was Rs. 17,453 per annum per household. Its contribution to the total income was $4 \%$. Similarly the average income based on the household reported income 
was found Rs. 41,147 per household per annum. The income from farm machinery and rented out land per household also increased after diversification. From these sources the average income based on the total household was Rs. 9111 and 8489 per annum per household respectively, while it contribution was 2.10 and $1.96 \%$ to the total income of the household. The average income based on the household reported the income from the sources was Rs. 37,713 and 101,556 per household per annum from rented out land and farm machinery. The overall farm sources income contributing $31 \%$ to the total household income and the average income based on the total household was Rs. 132,620 per household per annum after diversification of income.

From non-farm income sources mostly the diversification took place. The overall non-farm income contribution to the total income after diversification was $69 \%$ and the average income per household was Rs. 300,811 per household per annum. Thus it is clear from the findings that the contribution of non-farm income increased after diversification. Among the non-farm income sources the income from services was contributing $26 \%$ to the total household income after diversification followed by small scale business $14 \%$ and remittance $16 \%$ to the total household income after the diversification of income. From all sources the average income of the household based on total household was Rs. 433,390 per household per annum. The farm and non-farm income ratio was 0.44 after the diversification of household income. This indicated that the contribution of non-farm income to the total household was more than the farm income.

Table 1. Contribution of different livelihood sources to total income after diversification

\begin{tabular}{|c|c|c|c|c|c|}
\hline Source of livelihood & $\begin{array}{l}\text { Average HH income based } \\
\text { on total HH (Rs.) }(n=323)\end{array}$ & Percent & $\begin{array}{l}\text { Number of Households } \\
\text { reporting income }\end{array}$ & $\begin{array}{l}\text { Percent of } \mathrm{HH} \\
\text { reporting income }\end{array}$ & $\begin{array}{l}\text { Average income of } \\
\text { reporting household }\end{array}$ \\
\hline Crops & 65340 & 15.08 & 262 & 81.11 & 80553 \\
\hline Fodder & 1891 & 0.44 & 64 & 20.43 & 9227 \\
\hline Vegetable & 786 & 0.18 & 11 & 3.41 & 23091 \\
\hline Fruits & 5461 & 1.26 & 125 & 38.70 & 14111 \\
\hline (All crops) & 73479 & 16.95 & - & - & - \\
\hline Livestock & 17453 & 4.03 & 137 & 42.41 & 41147 \\
\hline Agric: wages & 3796 & 0.88 & 66 & 20.43 & 18576 \\
\hline [Agriculture] & 94727 & 21.86 & - & - & - \\
\hline Forest & 20293 & 4.68 & 201 & 62.23 & 32609 \\
\hline \{Agriculture and forestry\} & 115020 & 26.54 & - & - & 32609 \\
\hline Rented out land & 9111 & 2.10 & 78 & 24.15 & 37731 \\
\hline Farm machinery & 8489 & 1.96 & 27 & 8.36 & 101556 \\
\hline Farm sources total & 132620 & 30.60 & - & - & - \\
\hline Small scale business & 61412 & 14.17 & 122 & 37.77 & 162590 \\
\hline Wages & 11593 & 2.67 & 122 & 37.77 & 30598 \\
\hline Home remittance & 41406 & 9.55 & 149 & 46.13 & 89758 \\
\hline Foreign remittance & 29554 & 6.82 & 48 & 14.86 & 198875 \\
\hline (Remittances) & 70960 & 16.37 & - & - & - \\
\hline Public private services & 113687 & 26.23 & 157 & 48.61 & 233892 \\
\hline Pension & 3065 & 1.21 & 9 & 2.48 & 108750 \\
\hline Other sources & 40466 & 9.34 & 190 & 58.82 & 68792 \\
\hline Non-Farm sources Total & 300811 & 69.40 & - & - & - \\
\hline $\begin{array}{l}\text { All source } \\
\end{array}$ & 433390 & 100.00 & 323 & 100.00 & 433390 \\
\hline Farm: Non-farm Ratio & \multicolumn{5}{|c|}{0.440876} \\
\hline
\end{tabular}

Source: Field data

\subsection{Change in Contribution of Different Sources to Total Income after Diversification}

Empirical evidence support our findings that diversification is the most important way for reducing rural poverty and increasing household income (Hengsdijk et al., 2007). Data in Table 2 depict the average changes in households' income along with changes in percent contribution to total income before and after diversification. The data show that among the farm sources of income the average income from crop was Rs. $15,236 /$ - per household per annum, while its percent contribution to total household income has decreased. Similarly the change in average income from livestock and home remittances also taken place but contributed negatively to household income, followed by rented-out land contribution. Among the farm sources of income the contribution of tractor income contributed positively to household income. The findings show that the contribution of total income from farm sources was decreased by $10 \%$ after the diversification of income.

Among the non-farm income sources of income changes occurs in all the sources and the average income of the household increased for non-farm sources. The contribution of the non-farm sources of income to the total household income increased, among the non-farm sources the highest contribution (12\%) was noted from remittances (both home and foreign). The overall average change in from farm and non-farm income sources was Rs. 150,831 per annum per household after the diversification of income and the percent contribution increased by $10 \%$ after the diversification of income. The agriculture to nonagriculture ratio decrease to 0.4408 after the diversification of income. The findings clearly show that average income from the farm sources decreased while from non-farm sources increased.

Similar findings were reported by John and Wobst (2006) who stated that in rural Tanzania non-farm activities contributing more than farming activities to the household income. Davis et al. (2007) also mentioned that 
in the rural areas of developing world non-farm income contributing more to total household income and it is also one of the important reasons for household income diversification. Reardon (1997) supported the above findings that in rural Africa the non-farm sector contributing to more household income than the farm sector.

Table 2. Contribution of different livelihood sources to total income with diversification

\begin{tabular}{|c|c|c|c|c|c|c|}
\hline \multirow{2}{*}{ Source of livelihood } & \multicolumn{3}{|c|}{ Average annual income of $\mathrm{HH}$ of the total household } & \multicolumn{3}{|c|}{ Percent contribution of the source of income to total income } \\
\hline & Before & After & Change & Before & After & Change \\
\hline Crops & 50104 & 65340 & 15236 & 19.84 & 15.08 & -4.76 \\
\hline Fodder & 1013 & 1853 & 840 & 0.40 & 0.43 & 0.03 \\
\hline Vegetable & 320 & 786 & 466 & 0.13 & 0.18 & 0.05 \\
\hline Fruits & 2441 & 5461 & 3020 & 0.97 & 1.26 & 0.29 \\
\hline (All crops) & 53878 & 73479 & 19562 & 23.34 & 16.95 & -4.08 \\
\hline Livestock & 12716 & 17453 & 4737 & 5.03 & 4.03 & -1.01 \\
\hline Agric: Wages & 3610 & 3796 & 186 & 1.43 & 0.88 & -0.55 \\
\hline [Agriculture] & 74531 & 94727 & 20197 & 29.50 & 21.86 & -5.46 \\
\hline Forest & 14200 & 20293 & 6093 & 5.62 & 4.68 & 0.94 \\
\hline \{Agriculture and forestry\} & 94823 & 115020 & 20197 & 37.54 & 26.54 & -4.52 \\
\hline Rented out land & 6217 & 9111 & 2895 & 2.46 & 2.10 & -0.36 \\
\hline Farm machinery & 1594 & 8489 & 6895 & 0.63 & 1.96 & 1.33 \\
\hline Farm related sources & 102634 & 132620 & 29986 & 40.63 & 30.60 & -3.55 \\
\hline Small scale business & 29467 & 61412 & 31944 & 11.67 & 14.17 & 2.50 \\
\hline Wages & 6022 & 11593 & 5571 & 2.38 & 2.67 & 0.29 \\
\hline Home remittance & 9793 & 41406 & 31613 & 3.88 & 9.55 & 5.68 \\
\hline Foreign remittance & 279 & 29554 & 29276 & 0.11 & 6.82 & 6.71 \\
\hline (Remittances) & 10071 & 70960 & 60889 & 3.99 & 16.37 & 12.39 \\
\hline Public and private services & 61817 & 113687 & 51870 & 24.47 & 26.23 & 1.76 \\
\hline Pension & 3065 & 3065 & 0 & 1.21 & 1.21 & 0 \\
\hline Other sources & 39537 & 40466 & 929 & 15.65 & 9.34 & -6.32 \\
\hline Non-farm & 149980 & 300811 & 150831 & 59.37 & 69.40 & 10.03 \\
\hline All source & 252578 & 433390 & 180812 & 100.00 & 100.00 & - \\
\hline Farm: Non-farm Ratio & 0.6843 & 0.440876 & - & - & - & - \\
\hline
\end{tabular}

Source: Field data

Table 3. Change of income of the reported household from different livelihood sources

\begin{tabular}{|c|c|c|c|c|c|c|c|c|}
\hline \multirow[t]{2}{*}{ Source of livelihood } & \multicolumn{3}{|c|}{ Number of $\mathrm{HH}$ reporting the income } & \multicolumn{5}{|c|}{ Average HH income (in Rs.) of the reported households } \\
\hline & Before & After & Change & Before & t-test before & After & t-test after & Change \\
\hline Food crops & 262 & 262 & 0 & 61770 & \multirow{17}{*}{$\begin{array}{c}\text { Mean }=66216 \\
\text { Std. Dev. }=50993 \\
\text { WWWWWWWWWWStd. Error }=12748\end{array}$} & 80553 & \multirow{17}{*}{$\begin{array}{c}\text { Mean }=78281 \\
\text { Std. Dev. }=68600 \\
\text { Std. Error }=17150\end{array}$} & 18783 \\
\hline Fodder & 64 & 64 & 0 & 6766 & & 9266 & & 2500 \\
\hline Vegetable & 11 & 11 & 0 & 15400 & & 23091 & & 7691 \\
\hline Fruits & 125 & 125 & 0 & 90500 & & 14111 & & 4611 \\
\hline Livestock & 137 & 137 & 0 & 29980 & & 41147 & & 11168 \\
\hline Agricultural wages & 66 & 66 & 0 & 12000 & & 17938 & & 5938 \\
\hline Forest & 201 & 201 & 0 & 25400 & & 32609 & & 7209 \\
\hline Land rented out & 63 & 78 & 15 & 31873 & & 37731 & & 5858 \\
\hline Farm machinery & 5 & 27 & 22 & 103000 & & 101556 & & 1444 \\
\hline Small scale business & 64 & 122 & 58 & 148719 & & 162590 & & 13871 \\
\hline Wages & 73 & 122 & 49 & 26562 & & 30598 & & 4037 \\
\hline Home remittance & 53 & 149 & 96 & 59679 & & 89758 & & 30079 \\
\hline Foreign remittance & 1 & 48 & 47 & 90000 & & 198875 & & 108875 \\
\hline Public/private services & 111 & 157 & 46 & 179883 & & 233892 & & 54009 \\
\hline Pension & 9 & 9 & 0 & 110000 & & 110000 & & 0 \\
\hline Other sources & 188 & 190 & 2 & 67928 & & 68792 & & 864 \\
\hline \multirow[t]{2}{*}{ All source } & 323 & 323 & - & 252578 & & 433390 & & 180812 \\
\hline & \multicolumn{8}{|c|}{$\mathrm{p}=0.57653$} \\
\hline
\end{tabular}

Source: Field data

\subsection{Change of Income Based on the Reported Household from Different Livelihood Sources}

Rural households in the developing countries specialized in non-farm activities for livelihood because of fragmentation and low productivity of land. This results in switching of people from the farm sources of income to non-farm activities for secure and sustainable livelihood Davis et al. (2007). Data presented in Table 3 shows the number of households and their average income before and after diversification and changes of average income from farm and non-farm sources. The results show that 262 households reported for crop income before and after the diversification of income with an average increased of Rs. 18783/- per household per annum followed by livestock average income of Rs. 11168/-. Among the farm sources next to farming is the rented land and tractor income and the average change was Rs. 5858/- and Rs.1444/respectively. While no change occurred in the remaining farm income source after the diversification of income.

Among the non-farm income sources after the diversification of income 58 more household reported from self employment/business and the average change 
per household was Rs. 13871/- per household per annum. The other sources of the non-farm changes occurred both at the reported households and in the average income of the household after the diversification of income. From all sources of income the change was Rs. 180812/- per annum per households. The findings show that after the diversification of income the average income of the households' increased both from farm as well as from non-farm sources. But the contribution of non-farm sources was greater than the farm sources of income to the total household income. The p-value of the student's t-test explains that $57.65 \%$ change results in the income of the households as a result of the diversification.

\section{Conclusion and Recommendations}

It was observed during the survey that the majority of the households had switched over to other occupations or within the same source of livelihood had intensified their activities. This process of diversification had affected positively the household income. Diversification has a positive impact on the household income. This positive can be attributed to adoption of latest technologies by the rural households. The rural households diversified their income from both the farm and non-farm sources. The farm sources of livelihood including crop and livestock activities of the households' were diversified because of adopting the new verities of crops seeds and improved breeds of animals. The other sources of farm income i.e. fodder cultivation, vegetable, agriculture daily wages and forest related activities of the sample households' remain unchanged. Similarly the income from farm machinery and rented out land per household also increased after diversification. Farm sources income contributing 30.60\% to the total households' income and the average income based on the total household was Rs. 1,326,20/- per household per annum after diversification. From non-farm income sources mostly the diversification took place. The farm and non-farm income ratio was 0.44 after the diversification of households' income. The contribution of total income from farm sources was decrease by $10.03 \%$ after the diversification of income, while the contribution of the non-farm sources of income to the total household income increased. Among the non-farm sources the highest contribution (12.39\%) was noted from both home and foreign remittances. The agriculture to nonagriculture ratio decreased to 0.4408 after the diversification of income. Average income from farm and non-farm sources before and after diversification changed. Crop income before and after the diversification of income increased by Rs. 18,783/- per household per annum followed by livestock Rs. 11,168 average income. Among the non-farm income sources after the diversification of income self employment/business and the average change per household was Rs. 13871/- per household per annum. The other sources of the non-farm changes occurred both at the household reported level and in the average income of the household after the diversification of income. The overall change in income was recorded as Rs. 1,80,812/per household per annum. On the basis of study findings it is recommended that further improvements in both the farm and non-farm sources of income is required for sustainable livelihood and this can be done by investing more in the productive capitals of the rural households for inclusive rural development.

\section{References}

[1] Chambers, R. and Conway, R. (1992). Sustainable rural livelihoods: Practical concepts for the $21^{\text {st }}$ century. IDS discussion paper, No. 296. pp.127-130.

[2] Cochran, W.G. (1963). Sampling Techniques, $2^{\text {nd }}$ Ed., John Wiley and Sons, Inc. New York. Retrieved Aug. 21, 2013, from: edis.ifas.ufl.edu/pd006

[3] Davis, B., P. Winters, G. Carletto, K. Covarrubias, E. Quinones, A. Zezza, K. Stamoulis, G. Bonomi and S.D. Giuseppe. 2007. Rural income generating activities: A cross country comparison. ESA Working Paper No. 07-16. Retrieved April 30, 2013: www.fao.org/es/esa.

[4] Diez, H.M., S.Matee and W.Ssali. (2000). Assessment of the small-scale food processing subsector in tanzania and Uganda. Suffolk: Technical centre for agricultural and rural cooperation.

[5] Ellis, F. (2005). Small farms livelihood diversification, and ruralurban transitions: strategic issues in Sub-Saharan Africa. The future of small farms. Kent, UK: IFPRI, Overseas Dev. Ins. and Imperial College. pp. 135-149.

[6] Ellis, F. and H.A., Freeman. (2004). Rural livelihoods and poverty reduction strategies in four african countries. J. of Dev. Studies 40(4), pp.1-30.

[7] Ellis, F., Ssewanyana, S., B. Kebede and E. Allison. (2006). Patterns and changes in rural livelihoods in uganda 2001-05: Findings of the LADDER 2 project. Eco. Policy Res. Centre and Overseas Dev. Group.

[8] Ellis, F. (2000). Rural livelihoods and diversity in developing countries. New York: Oxford Uni. Press Inc.

[9] Hengsdijk, H., W. Guanghuo, M. Marrit, V. Berg, W. Jiangdi, J.L. Wolf, C. Reimund, P. Roetter and H.V. Keulen. (2007). Poverty and biodiversity trade-offs in rural development: A case study for Pujiang County, China, J. Agric. Systems, 94 (4): 851-861, Retrieved Oct. 20, 2013: www.elsevier.com/locate/agsy.

[10] Hussein, K. and J.Nelson. (1998). Sustainable livelihoods and livelihood diversification. Brighton: Ins. of dev. studies. Int. Dev. Assoc., Int. Finan. Coop. and Multilateral Inv.

[11] John K.M. and P. Wobst. 2006. Determinants of rural labor market participation in Tanzania. Center for Develop. Res. (ZEF), Univ. Bonn. Pp. 1-30. Retrieved Oct. 20, 2013, http://www.zef.de/module/register/media/bdecasq_mduma\%20_w obst\%20_sent_publication_aug2004.pdf

[12] Kim, H. (2011). Livelihood diversification in rural Uganda: Its pattern and contribution to income generation with a focus on the role of social network. M.Sc, Development Studies dissertation, School of Oriental and African Studies, Uni. of London, pp. 04-08

[13] Losch, B., S.Fréguin-Gresh, and E. White. (2010). Structural dimensions of liberalization on agriculture. Washington D.C.: World Bank.

[14] Reardon, T. (1997). Using evidence of household income diversification to inform study of the rural nonfarm labor market in Africa. World Development 25 (5), 735-747.

[15] Smith, D.R., A.Gordon, K Meadows and K. Zwick. (2001). Livelihood diversification in Uganda: Patterns and determinants of change across two rural districts. Food Policy, 421-435.

[16] World Bank, (2008).World development report: Agriculture and development. pp. 177-179. 